\title{
ANTICANCER AND FREE RADICAL SCAVENGING POTENTIAL OF THE MARINE ALGICOLOUS ENDOPHYTIC FUNGUS CLADOSPORIUM UREDINICOLA
}

\author{
VASAVI THIRUMALANADHUNI, LAVANYA LATHA YERRAGURAVAGARI ${ }^{2}$, VANI MATHAKALA ${ }^{3}$, \\ UMA MAHESWARI DEVI PALEMPALLI ${ }^{4}$
}

Department of Applied Microbiology, Sri Padmavathi Mahilavisvavidyalayam, Tirupati - 517 502, Andhra Pradesh, India. Email: vasavimicrobiology@gmail.com

Received: 08 December 2018, Revised and Accepted: 15 January 2019

ABSTRACT

Objective: The objective was to study the antioxidant and anticancer potential of the endophytic fungus Cladosporium uredinicola, isolated from the marine brown alga Dictyota dichotoma.

Methods: Anticancer effect of the endophytic fungal extract was evaluated by 3-(4, 5-dimethylthiazol-2-yl)-2, 5-diphenyltetrazolium bromide (MTT) assay using MDA-MB-231 human mammary adenocarcinoma cells as in vitro cancer models. 3T3-L1 pancreatic adipocytes were used as in vitro models for the evaluation of cytotoxic activity against normal cells using MTT assay. Free radical scavenging activity was assessed by 2, 2-diphenyl-1picrylhydrazyl (DPPH) assay.

Results: The ethyl acetate extract of the endophytic fungus showed potent cytotoxic activity against MDA-MB-231 human breast adenocarcinoma cell lines with an inhibitory concentration $\left(\mathrm{IC}_{50}\right.$ ) value of $373 \mu \mathrm{g} / \mathrm{ml}$ and a very mild cytotoxic effect on $3 \mathrm{~T} 3-\mathrm{L} 1 \mathrm{Cells}$ with an $\mathrm{IC}_{50}$ value of $2403 \mu \mathrm{g} / \mathrm{ml}$. $\mathrm{DPPH}$ free radical scavenging assay of the extract showed an $\mathrm{IC}_{50}$ value of $359 \mu \mathrm{g} / \mathrm{ml}$ indicating its potential free radical scavenging activity.

Conclusion: The results indicated that the endophytic fungus $C$. uredinicola, isolated from the marine brown alga $D$. dichotoma, acts as a potential source for anticancer and antioxidant metabolites. Moreover, these anticancer metabolites were observed to be less toxic to the normal cells, which make them prospective therapeutic agents.

Keywords: Marine endophytic fungi, Free radical scavenging, Cytotoxic, MDA-MB-231,3T3-L1 cells.

(C) 2019 The Authors. Published by Innovare Academic Sciences Pvt Ltd. This is an open access article under the CC BY license (http://creativecommons. org/licenses/by/4. 0/) DOI: http://dx.doi.org/10.22159/ajpcr.2019.v12i3.30977

\section{INTRODUCTION}

Marine environment is considered to be a reservoir of pharmaceutically important bioactive compounds due to its rich biodiversity and extreme physical and chemical conditions. In recent years, a number of bioactive compounds were isolated from the marine organisms such as sponges, seaweeds, and microorganisms. Some of these compounds are under pre-clinical and clinical trials [1]. More than 10,000 secondary metabolites were reported to be isolated from marine organisms [2]. Some anticancer compounds such as "hemiasterlin" from the sponges and "elisidepsin" from molluscs are under clinical trials [3].

Marine microorganisms are more advantageous than other marine organisms since they can be cultured and manipulated in the laboratory very easily. Several marine bacteria, Actinomycetes, and fungi were screened for bioactive metabolites [4]. Antifungal compounds such as basilikamides A and B, anticancer compounds such as bacillistatins 1 and 2 , and antioxidant compounds such as wentiquinone were reported from the marine microorganisms [2].

Among several marine microorganisms, marine endophytes are largely unexplored due to the problems associated in culturing them. Endophytes reside in the living tissues of the host without causing any apparent harmful effect. These peculiarities of lifestyle compel them to encounter host defense molecules continuously. It is that, due to this complexity, the endophytes were evolved to produce various unique metabolites, which could be exploited for pharmaceutical applications [5].

Cancer is one of the leading causes of mortality and morbidity worldwide. According to the definition given by the World Health Organization, cancer is a generic term for a large group of diseases that can affect any part of the body in which there is a rapid creation of abnormal cells that grow beyond their usual boundaries and invade adjoining parts of the body and spread to other organs. The American Cancer Society reported cancer as the second most common cause of death next to cardiovascular diseases in the USA and Europe. Resistance to anticancer compounds and side effects of the drugs are the major problems associated with chemotherapy. In this context, there is an urgent need to develop new and safe drugs for cancer treatment. In the past 20 years, an increasing number of pharmaceutically useful compounds were reported [3].

Of the eight marine drugs approved for various purposes, five compounds, namely cytarabine, ziconotide, trabectedin, eribulin mesylate, and brentuximab, have been approved for cancer treatment [6]. With this background, the present study was carried out to evaluate the free radical scavenging and anticancer potential of the marine algicolous endophytic fungus Cladosporium uredinicola isolated from the marine brown alga Dictyota dichotoma. In this study, the antioxidant activity was screened by 2, 2-diphenyl-1-picrylhydrazyl (DPPH) free radical scavenging assay, whereas cytotoxic activity on both cancer and normal cells was evaluated by 3-(4, 5-Dimethylthiazol2-yl)-2, 5-diphenyltetrazolium bromide (MTT) assay.

\section{METHODS}

\section{Chemicals}

Ethyl acetate (EA) was obtained from SD Fine-Chem Limited, Mumbai, India. DPPH, MTT, Dulbecco's Modified Eagle's Medium (DMEM), phosphate-buffered saline, trypsin - HyClone, and ciprofloxacin (cell culture) were procured from HiMedia Laboratories, Mumbai, India.

\section{Medium for culturing of endophytic fungi}

A novel medium by name "MGM medium" (patented) was formulated for culturing of endophytic fungi [7]. 


\section{Fungal culture}

The endophytic fungus isolated from marine alga $D$. dichotoma was coded as marine brown algal endophytic fungus (MBEF) and it was identified as C. uredinicola, by $28 \mathrm{~S}$ ribosomal DNA sequence analysis. The sequence was deposited at the GenBank under the accession number MG719993.

\section{Cell lines}

MDA-MB-231Cells and 3T3-L1 cells were procured from National Center for Cell Sciences, Pune, India.

\section{Extraction of the metabolites}

A 15-day-old culture broth of $C$. uredinicola was filtered using Whatman NO.1 filter paper, and the filtrate was extracted with an equal volume of EA. The organic phase was collected and dried in a rotary evaporator [8]. The EA extract was stored at $4^{\circ} \mathrm{C}$ for further analysis and designated as MBEF-EA extract.

\section{Free radical scavenging activity}

Antioxidant activity of the crude extract was detected by DPPH free radical scavenging activity assay [9,10]. A solution of $1 \mathrm{ml}$ of $0.1 \mathrm{mM}$ DPPH solution was added to different concentrations of the extract $(10-500 \mu \mathrm{g} / \mathrm{ml})$ and incubated at room temperature in the dark for $20 \mathrm{~min}$, and the intensity of the color was read at $517 \mathrm{~nm}$ using ultraviolet spectrophotometer.

The inhibitory percentage of DPPH was measured using the following formula:

$$
\text { Inhibitory\% of DPPH }=\frac{\begin{array}{l}
\text { Absorbance of control }- \\
\text { Absorbance ofsample }
\end{array}}{\text { Absorbance of sample }} \times 100
$$

\section{Cytotoxic activity of EA extract}

\section{Cell culture}

MDA-MB-231 estrogen receptor-negative human breast adenocarcinoma cell lines and 3T3-L1 murine pancreatic preadipocytes were routinely maintained in DMEM, supplemented with $2 \mathrm{mmol} / \mathrm{l}$ glutamine, $10 \%$ fetal bovine serum, and $10 \mu \mathrm{g} / \mathrm{ml}$ of ciprofloxacin in a $5 \% \mathrm{CO}_{2}$ incubator at $37^{\circ} \mathrm{C}$.

The cytotoxic activity of the extract was analyzed using MTT $[11,12]$. The MDA-MB-231 cells $\left(1 \times 10^{4} /\right.$ well $)$ and 3T3-L1 cells were seeded in 96 well plates and incubated for $24 \mathrm{~h}$ at $37^{\circ} \mathrm{C}$ in $5 \% \mathrm{CO}_{2}$ and then treated with different concentrations of the EA extract ranging from 100 to $500 \mu \mathrm{g} / \mathrm{ml}$ of the extract dissolved in $0.1 \%$ of dimethyl sulfoxide (DMSO). After $24 \mathrm{~h}$ exposure, $0.02 \mathrm{ml}$ of MTT $(5 \mathrm{mg} / \mathrm{ml}$ in phosphate buffer saline) was added to each well and incubation was extended for another $4 \mathrm{~h}$. The MTT solution was removed by aspiration and $0.15 \mathrm{ml}$ of DMSO was added to each well to solubilize the formazan crystals, and absorbance was read in microplate reader at $570 \mathrm{~nm}$.

The percentage proliferation for each treatment was calculated using the following formula:

$$
\text { Cell proliferation }(\%)=\frac{\text { Mean OD value ofthe test }}{\text { Mean OD value of the control }} \times 100
$$

\section{RESULTS}

Free radical scavenging activity of EA extract

The DPPH free radical scavenging activity of the extract is depicted in Table 1. The extract showed significant activity in dosedependent manner with a mean inhibitory concentration value of $359 \mu \mathrm{g} / \mathrm{ml}$.

\section{Cytotoxic activity}

The EA extract showed selective toxicity against cancer cells (Fig. 1). A potent cytotoxic activity of the EA extract of endophytic fungus against MDA-MB-231 human breast adenocarcinoma cell lines with an IC ${ }_{50}$ value of $373 \mu \mathrm{g} / \mathrm{ml}$ (Fig. 2) was observed. The extract was found to induce the visible symptoms of apoptosis, namely retraction, rounding, and granulation, in MDA-MB-231 cell lines (Fig. 3). There was a very mild cytotoxic effect of the extract observed on 3T3-L1 cells with an IC ${ }_{50}$ value of $2403 \mu \mathrm{g} / \mathrm{ml}$ (Fig. 4). Visible symptoms of apoptosis were induced by the extract at very higher concentrations only (Fig. 5).

\section{DISCUSSION}

India has a coastal line of $7516.6 \mathrm{~km}$ [13] holding several biomes and ecosystems. In the process of ongoing search for new bioactive compounds, marine environment is being explored in the recent years. The microbiota appears to be a promising source for novel pharmaceutical compounds as the microorganisms can be grown easily under laboratory conditions [14]. Despite this fact, majority of the marine microorganisms remained unexplored. Marine endophytes are among such microorganisms hidden in their hosts. Endophytes are universally found in the plants [15]. The salient properties of endophytes project them as prospective candidates for the extraction of novel metabolites with various biological activities [16].

In the present work, an endophytic fungus isolated from the marine brown algal $D$. dichotoma was subcultured and the culture broth was extracted with EA. As per the literature, EA seems to be the common

Table 1: DPPH free radical scavenging activity of MBEF-EA extract

\begin{tabular}{lll}
\hline $\begin{array}{l}\text { Concentration of } \\
\text { the extract }(\boldsymbol{\mu g} / \mathbf{m l})\end{array}$ & $\begin{array}{l}\text { Inhibition } \\
\text { percentage of DPPH }\end{array}$ & IC $_{\mathbf{5 0}}$ value $(\boldsymbol{\mu g} / \mathbf{m l})$ \\
\hline 100 & $16 \pm 0.1$ & 312.5 \\
200 & $26 \pm 0.2$ & 384.6 \\
300 & $43 \pm 0.1$ & 348.8 \\
400 & $57 \pm 0.1$ & 350.9 \\
500 & $63 \pm 0.2$ & 396.9 \\
\hline
\end{tabular}

The data represent mean \pm SEM of three independent experiments. MBEF-EA: Marine brown algal endophytic fungus-ethyl acetate, DPPH: 2, 2-diphenyl-1-picrylhydrazyl, IC F0 $_{50}$ : Inhibitory concentration, SEM: Standard error of the mean

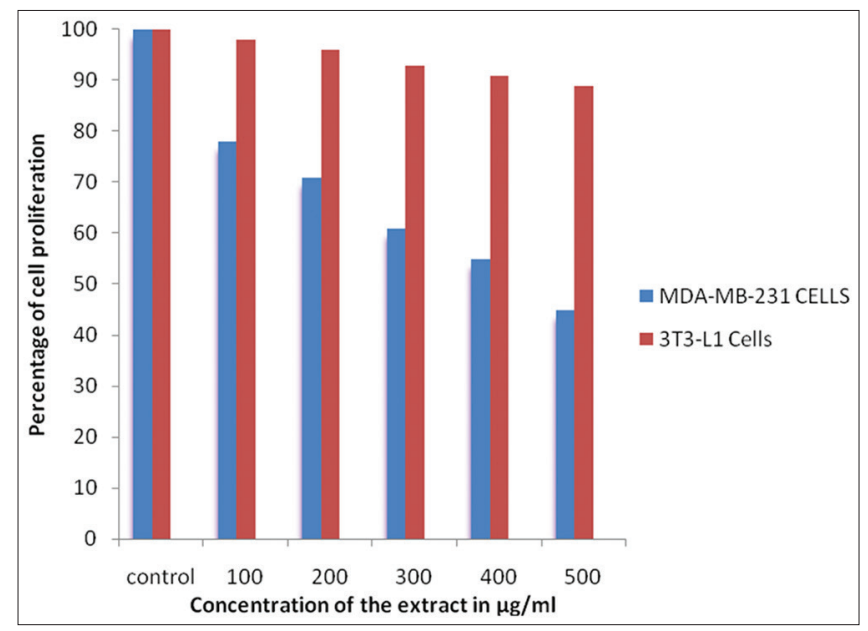

Fig. 1: Differential cytotoxic effect of the marine brown algal endophytic fungus-ethyl acetate extract on normal adipocytes (3T3-L1 cells) and breast cancer cells (MDA-MB-231 cells). Each bar represents the data of triplicate determinant, and there is a significant difference on comparison with control $(p<0.01)$ 


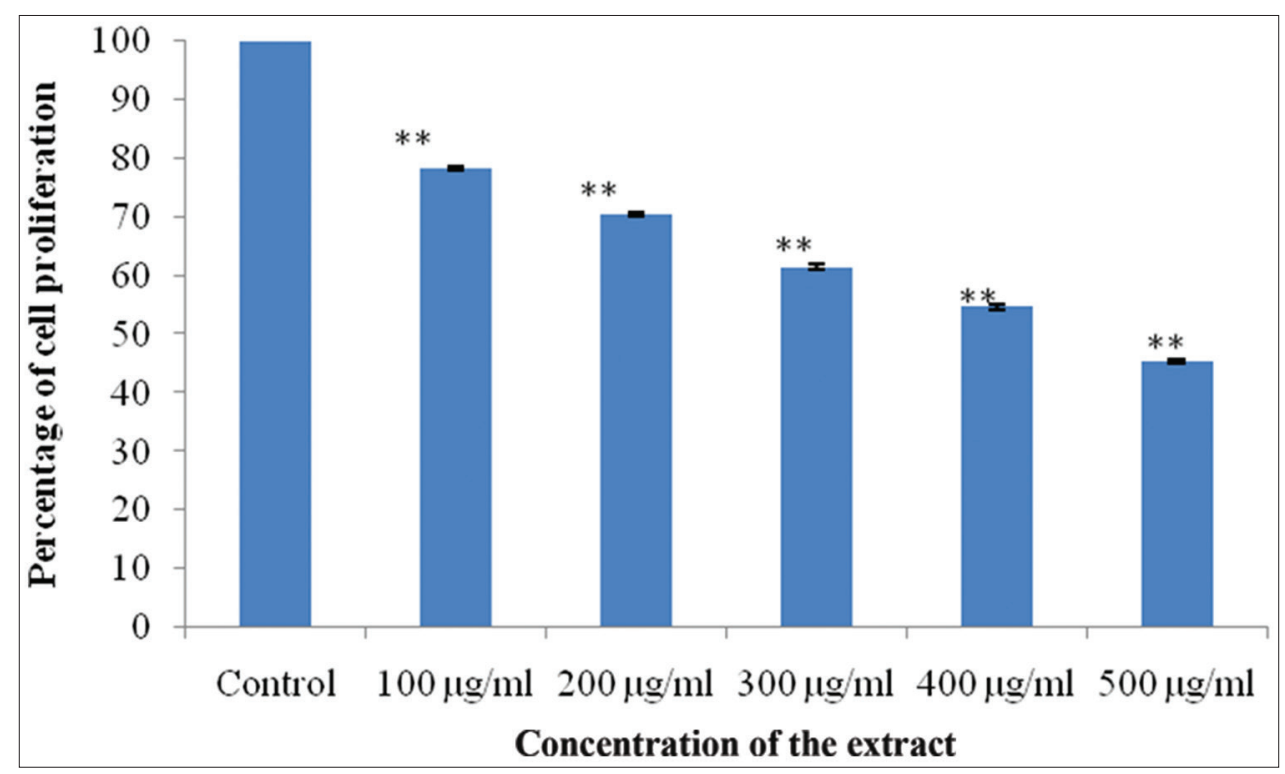

Fig. 2: Effect of marine brown algal endophytic fungus-ethyl acetate extract on the viability of MDA-MB-231 cells. The data are the average of three independent experiments. ${ }^{*}$ Indicates $\mathbf{p}<0.05, * *$ indicates $\mathbf{p}<0.01$

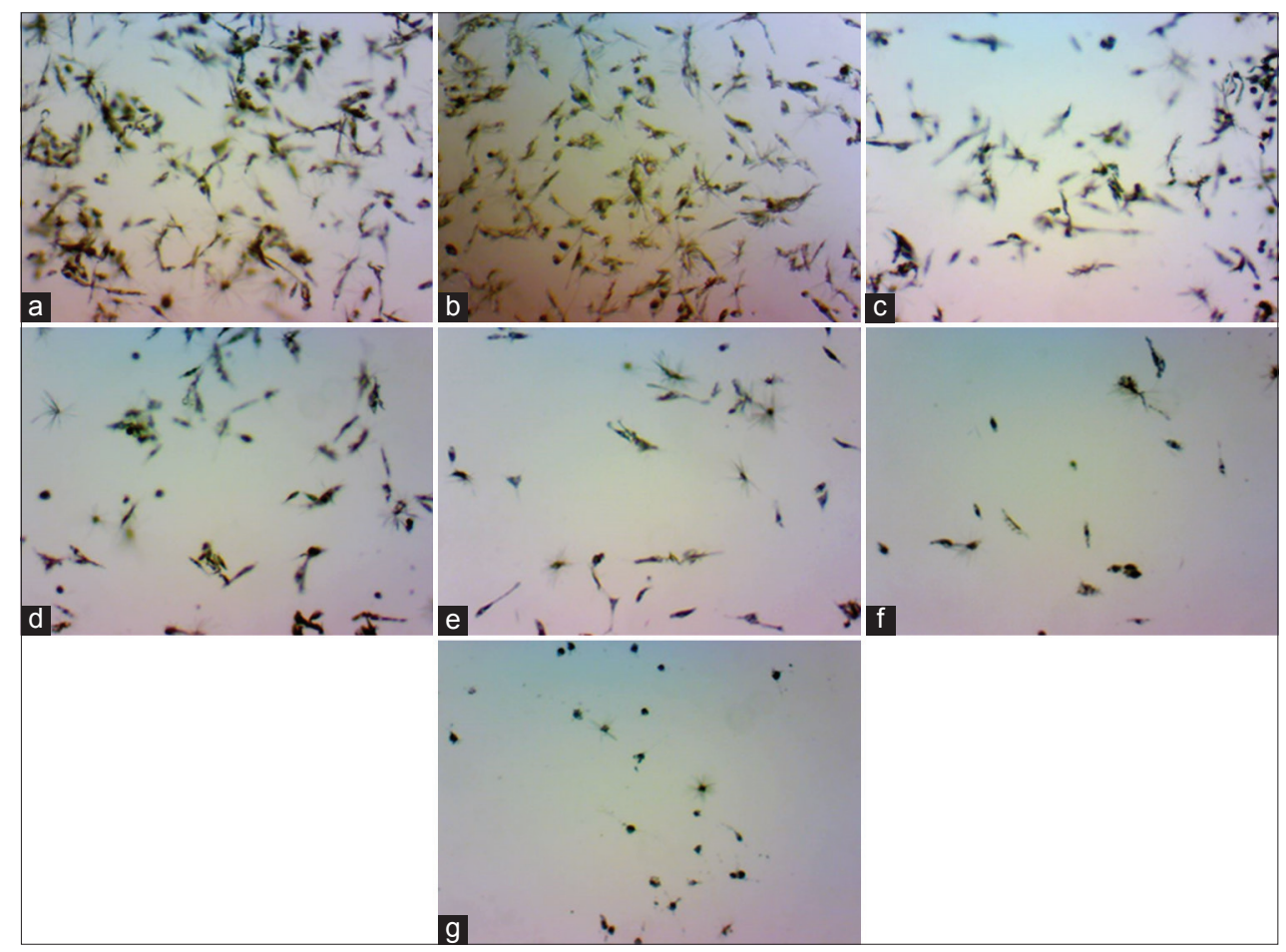

Fig. 3: Photomicrograph of inverted microscope depicting the cytotoxic effect of marine brown algal endophytic fungus-ethyl acetate (MBEF-EA) extract on MDA-MB-231 cells (a) Control (untreated cells), (b) dimethyl sulfoxide (vehicle control), (c) $100 \mu \mathrm{g} / \mathrm{ml}$,

(d) $200 \mu \mathrm{g} / \mathrm{ml}$, (e) $300 \mu \mathrm{g} / \mathrm{ml}$, (f) $400 \mu \mathrm{g} / \mathrm{ml}$, (g) $500 \mu \mathrm{g} / \mathrm{ml}$ of MBEF-EA

solvent used for screening bioactive metabolites of endophytic fungi [17]. From the results of the antioxidant activity, the extract was found to have free radical scavenging activity. The DPPH radical scavenging activity was reported with Wardomyces anomalus, inhabitant of Enteromorpha sps, and fungus Epicoccum sps. of marine alga Fucus vesiculosus [18]. From the results of the MTT assay, it can be concluded that the organic extract of the isolated endophytic fungus was found to have cytotoxic effect on cancer cells without much affecting the normal cells. Penicillium chrysogenum, an endophyte isolated from the marine red alga Laurencia, was found to show cytotoxic activity against human liver carcinoma cell line [19]. Similarly, norditerpenoid purified from Aspergillus wentii, an endophyte of Sargassum spp., demonstrated cytotoxicity against tumor cell lines [20]. Further analysis of the EA extract may reveal the bioactive principles responsible for the antioxidant and selective cytotoxic properties of the endophytic fungal extract.

\section{CONCLUSION}

From the results of the present work, it can be concluded that the endophytic fungus $C$. uredinicola isolated from the marine brown alga $D$. dichotoma was found to be a source of bioactive metabolites and worth exploring further. 


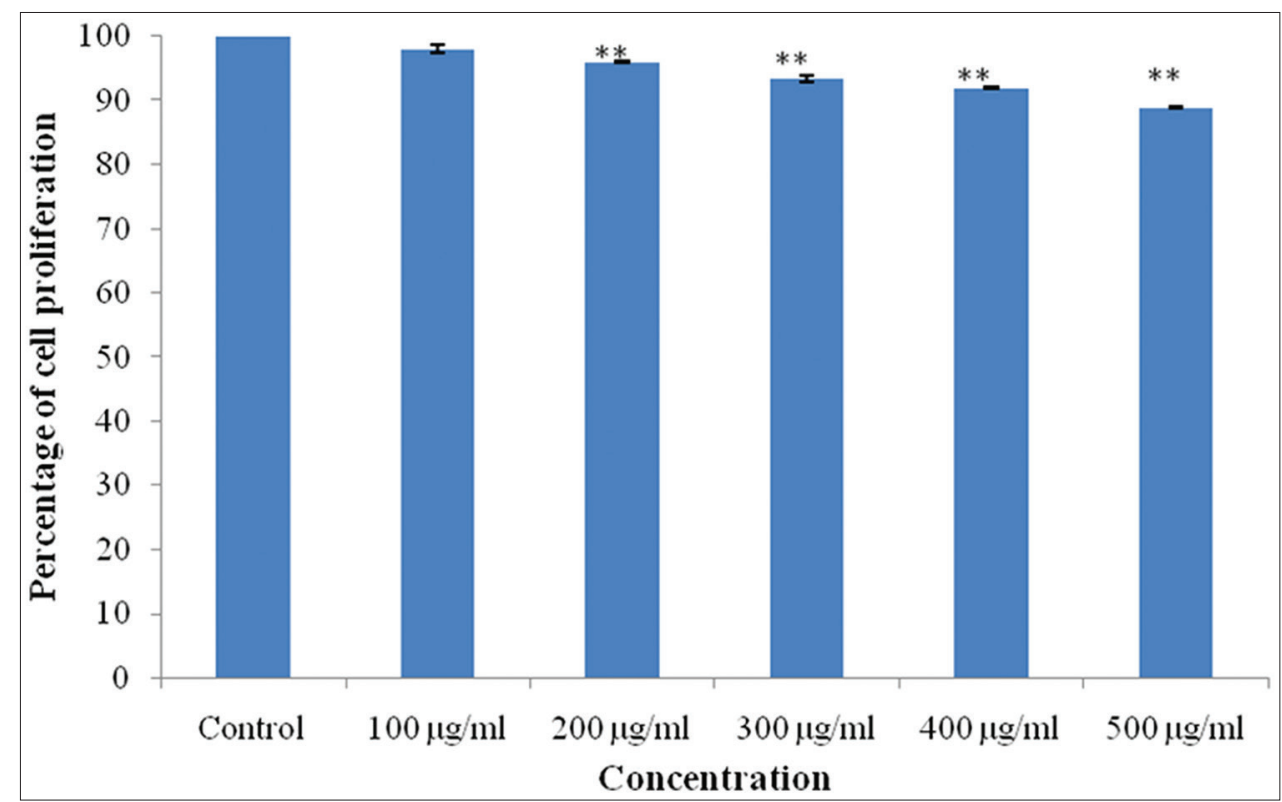

Fig. 4: Cytotoxic activity of the marine brown algal endophytic fungus-ethyl acetate against normal adipocytes 3T3-L1 cell line. The data represent the mean of three independent experiments. *p<0.05; **indicates $p<0.01$

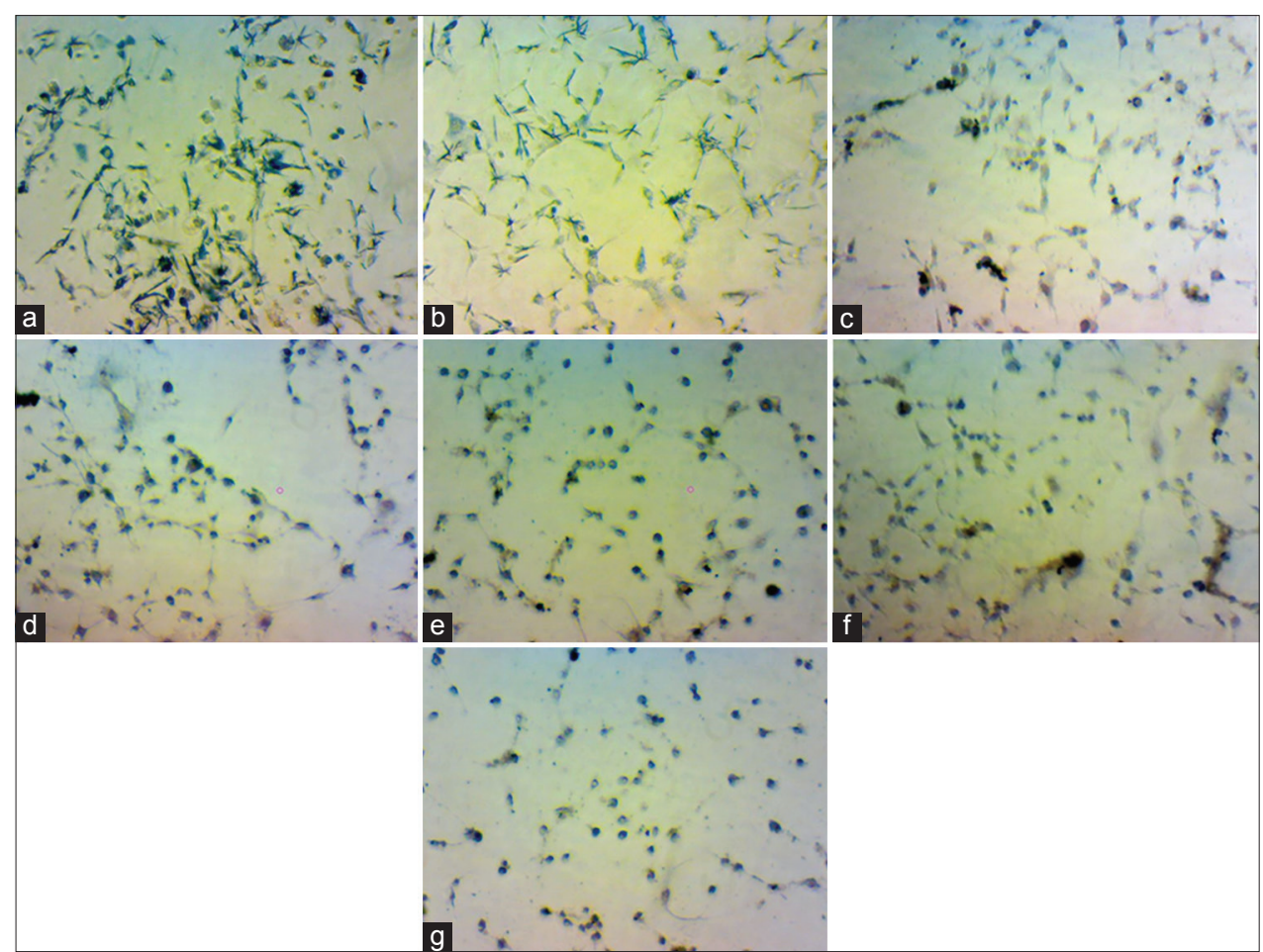

Fig. 5: Photomicrographs of optical-inverted microscopy demonstrating effect of marine brown algal endophytic fungus-ethyl acetate (MBEF-EA) extract on 3T3-L1 cells (a) control (untreated cells), (b) dimethyl sulfoxide (vehicle control), (c) $100 \mu \mathrm{g} / \mathrm{ml}$, (d) $200 \mu \mathrm{g} / \mathrm{ml}$, (e) $300 \mu \mathrm{g} / \mathrm{ml}$, (f) $400 \mu \mathrm{g} / \mathrm{ml}$, (g) $500 \mu \mathrm{g} / \mathrm{ml}$ of MBEF-EA extract

\section{ACKNOWLEDGMENTS}

The authors are grateful to DST-CURIE (Sri Padmavathi Mahila Visvavidyalayam, Tirupati) for their support.

\section{AUTHORS' CONTRIBUTIONS}

V.T and U.D were involved in design, planning, execution, data analysis, and manuscript preparation. L.Y and V.M were involved in cell culture work and also contributed to manuscript preparation.

\section{CONFLICTS OF INTEREST}

The authors have no conflicts of interest.

\section{REFERENCES}

1. Hussain S, Fareed S, Ansari S, Khan SM. Marine natural products: A lead for anti-cancer. Indian J Geo-Marine Sci 2012;41:27-39.

2. Shukla S. Secondary metabolites from marine microorganisms and therapeutic efficacy. Indian J Geo-Marine Sci 2014;45:1245-54. 
3. Ruiz-Torres V, Encinar JA, Herranz-López M, Pérez-Sánchez A, Galiano V, Barrajón-Catalán E, et al. An updated review on marine anticancer compounds: The use of virtual screening for the discovery of small-molecule cancer drugs. Molecules 2017;22:234-67.

4. Debbab A, Aly AH, Lin WH, Proksch P. Bioactive compounds from marine bacteria and fungi. Microb Biotechnol 2010;3:544-63.

5. Selim KA, El-Beih AA, El-Rahman TM, El-Diwany A. Biology of endophytic fungi. Curr Res Environ Appl Mycol 2012;2:31-82.

6. Mudit M, El Sayed KA. Cancer control potential of marine natural product scaffolds through inhibition of tumor cell migration and invasion. Drug Discov Today 2016;21:1745-60.

7. Devi PU, Vasavi T. 'MGM Medium'. Indian Patent Application Number 201641020940. Available from: http://www.ipindiaservices.gov.in.

8. Deng CM, Liu SX, Huang CH, Pang JY, Lin YC. Secondary metabolites of a mangrove endophytic fungus Aspergillus terreus (No. GX7-3B) from the South China Sea. Mar Drugs 2013;11:2616-24

9. Li X, Li XM, Xu GM, Li CS, Wang BG. Antioxidant metabolites from marine alga derived fungus Aspergillus wentii. Phytochem Lett 2014;7:120-12.

10. Hakkim F, Achankunju J, Hasan S. In vitro DPPH radical scavenging and anti-bacterial activity of Oman's Cymbopogon. Int J Pharm Pharm Sci 2016;8:329-31.

11. Navya A, Rashmi H, Prasad OH, Maheswaridevi Pu. Anti-proliferation and apoptosis induction by a-mangostin on MDA-MB-231 human breast cancer cell line.Int J Appl Pharm Res 2013;4:2222-9.
12. Mahadev R, Ramakrishnaiah H, Krishna V, Deepalakshmi A, Kumar N. Cytotoxic activity of methanolic extracts of Solanum erianthum d. don. Int J Pharm Pharm Sci 2014;7:106-8.

13. Available from: https://www.mapsofindia.com

14. Romano G, Costantini M, Sansone C, Lauritano C, Ruocco N, Ianora A, et al. Marine microorganisms as a promising and sustainable source of bioactive molecules. Mar Environ Res 2017;128:58-69.

15. Tan RX, Zou WX. Endophytes: A rich source of functional metabolites. Nat Prod Rep 2001;18:448-59

16. Sarasan M, Puthumana J, Job N, Han J, Lee JS, Philip R, et al. Marine algicolous endophytic fungi - A promising drug resource of the era. J Microbiol Biotechnol 2017;27:1039-52.

17. Abdel-Lateff A, König GM, Fisch KM, Höller U, Jones PG, Wright AD, et al. New antioxidant hydroquinone derivatives from the algicolous marine fungus Acremonium sp. J Nat Prod 2002;65:1605-11.

18. Abdel-Lateff A, Klemke C, König GM, Wright AD. Two new xanthone derivatives from the algicolous marine fungus Wardomyces anomalus. J Nat Prod 2003;66:706-8.

19. Gao SS, Li XM, Li CS, Proksch P, Wang BG. Penicisteroids A and B, antifungal and cytotoxic polyoxygenated steroids from the marine algaderived endophytic fungus Penicillium chrysogenum QEN-24S. Bioorg Med Chem Lett 2011;21:2894-7.

20. Sun HF, Li XM, Meng L, Cui CM, Gao SS, Li CS, et al. Asperolides A-C, tetranorlabdane diterpenoids from the marine alga-derived endophytic fungus Aspergillus wentii EN-48. J Nat Prod 2012;75:148-52. 